\title{
A estética do vazio nas polaroids de Charif Benhelima
}

[Charif Benhelima: Polaroids, 1998-2012,
Museu Oscar Niemeyer, Curitiba]

Vanessa Santos ${ }^{1}$

http://dx.doi.org/10.22409/poiesis.1932.175-178

A mostra foi dividida em quatro séries: Harlem on My Mind: I was, I am (1999-2002), Semites (2003-2005), Black-out (2005 - 2014) e Roots (2008 - 2015). Na entrada da exposição algo chama atenção ao olhar: há um enorme espaço vazio na galeria além das luzes no ambiente, brancas, o que deixa a sala com um aspecto visualmente limpo e claro. Ao fundo, encontra-se uma obra em grande escala em cores quentes, parece ser um homem de costas, sua identidade é silenciada pelo processo no qual a imagem foi realizada, provém de uma das séries em polaroids feitas pelo artista belga. São ao todo aproximadamente 130 polaroids nesta exposição e três obras em grande formato, feitas a partir das polaroids, divididas em quatro séries: Harlem on My Mind: I was, I am (1999-2002), Semites (2003-2005), Black-Out (2005 - 2014) e Roots (2008 - 2015).

\footnotetext{
${ }^{1}$ Vanessa Santos é artista visual e docente no Instituto Federal de Educação, Ciência e Tecnologia (IFRJ). Mestre em Artes Visuais (Linguagens Visuais) pelo PPGAV-EBA-UFRJ. E-mail: vanessa_qdv@hotmail.com
} 
Iniciada pelo Palais de Beaux-Arts (BOZAR), em Bruxelas, a exposição já esteve no Brasil anteriormente no MAC-Niterói no período de 06 de abril a 23 de junho de 2013. Recentemente retornou ao ser exposta pelo Museu Oscar Niemeyer com o título de Charif Benhelima: Polaroids, 1998-2012. A mostra é uma retrospectiva da pesquisa feita pelo artista que, além de problematizar questões advindas deste meio como o tempo de autorrevelarse da própria imagem, por exemplo, traz questões primordiais como a noção de apagamento físico e/ou metafórico da fotografia, o esvaziamento da identidade, o pertencimento a uma cultura ou povo. Noções como origem, memória e esquecimento, tempo, espaço são centrais à obra de Benhelima, cuja história familiar constitui-se de diversos hiatos. FiIho de pai marroquino e mãe belga, o artista ficou órfão aos oito anos e cresceu no interior de Flandres Ocidental; mais tarde aprendeu sobre sua origem judaica, algo presente em seu trabalho, que aparece de forma clara na série Semites (2003-2005). Nela, o artista mostra fotografias de imigrantes judeus, a maioria com a face apagada pela luz em excesso.

Logo na primeira parede à direita da porta de entrada da galeria do MON estão duas das quatro séries ali expostas. São Roots (2008-2015) e Black-Out (2005-2014). Assim, como a primeira impressão que se tem ao entrar na sala, o aspecto esvaziado tomado pelo branco aparece em todos os trabalhos que constituem esta exposição, no entanto, cada um à sua maneira. O branco nesta primeira parte da sala é quase total. $O$ espectador se esforça para enxergar o que é fotografado, na tentativa de formar a imagem que começa ali na polaroid e que, por fim, se constitui na imaginação de quem as vê. Ambas as séries foram realizadas em um período muito próximo com datas que se entrecruzam e a diferença não está no modo de fotografar nem tampouco no meio utilizado. Mesmo assim revelam-se duas abordagens diferentes sobre uma mesma questão: o esvaziamento progressivo da imagem. Enquanto em Black-Out a narrativa visual parte de objetos, edifícios, passagens, em Roots estão presentes formas mais orgânicas como plantas, flores e vegetações. A sensação de ausência das formas às quais as fotografias remetem é prolongada para além das bordas do que é fotografado. Assim, ultrapassa os limites da própria moldura tomando o branco das paredes e terminando nas memórias e fantasias - lembradas

Poiésis, Niterói, v. 19, n. 32, jul./dez. 2018. 
e esquecidas - de quem as observa. O que há ali para além do que é fotografado? Constantes ausências que insistem em se manter para sempre veladas ou pelo menos parcialmente veladas. Assim como se constituem memórias de um tempo muito remoto já quase que completamente esquecido dentro do sujeito, se mostra presente ao pulsar por entre pequenas e breves brechas que afirmam sua posição. De forma geral, ao olhar sua produção pelo viés desta exposição, o que Benhelima parece fotografar são recortes de pequenas apreensões avulsas, detalhes de coisas encontradas no seu cotidiano. Observações muito singelas de pontos esvaziados em um constante desejo de reescrever fantasias em parte captadas ou rememoradas. Texturas e fragmentos de coisas feitas tanto pelo homem quanto aquelas encontradas na natureza. Uma se interpela na outra ao revelar-se no próprio branco turvo do papel brilhoso da polaroid. Sempre fragmentadas, essas imagens, ao mesmo tempo em que aparecem, desaparecem. São capturadas no dia a dia com uma máquina fotográfica portátil, "amadora". São verdadeiros desvios da linguagem, de algo que remete a outra coisa, ou até mesmo a associações livres que ao apresentarem-se já se configuram eternamente como uma falta. Estas fotografias são como presenças de ausências em si mesmas. Já se perderam na tentativa de autorrevelarem-se. 0 branco é constante, aparece em quase todas as imagens expostas, sempre dificultando que se enxergue toda a imagem, ao cobrir rostos e identidades na série Semites, ao fragmentar figura, fundo e objetos nas demais séries expostas. Ao buscar uma completude das formas que se dão nas imagens, se configura um vazio tremendo daquilo que nunca aparecerá por completo.

Uma das fotografias da série Black Out leva o nome de Minus Two (2006). Nela, não se sabe ao certo como é o local onde estão os dois balanços feitos de pneus que aparecem suspensos no topo da imagem. Não se tem referências de onde estão localizados, se em uma casa, ou em um parque, se alguém passou por ali há pouco ou não. Contudo, uma coisa é certa: a forte presença do branco sobre a fotografia. A narrativa contida nessa imagem estará para sempre velada, ao permanecer escondida sob uma superfície que a cobre como uma névoa, volátil em sua própria singularidade ao colocar-se como um ponto de partida a ser percorrido e habitado pelo espectador. Revela-se muito delicadamente 
como uma história que tem seus primeiros traços marcados em uma folha de papel em branco. É o espectador que dará prosseguimento em cada uma dessas narrativas contidas nas polaroids ali expostas. Cada uma dessas imagens se revela como pequenas histórias parcialmente lembradas, totalmente fragmentadas. Mostram-se como memórias breves que são ativadas por algo que está contido em uma cena corriqueira. São sempre signos comuns, pneus, plantas, janelas, lata de lixo, em um parque, em uma vizinhança, em uma rua, em uma praia ou no quintal da casa do vizinho.

Ao apropriar-se deste fragmento de imagem revela-se como um lugar que já se esvaiu em uma velocidade tão grande quanto à própria velocidade da luz branca. O tempo é novamente posto como questão enquanto sua brevidade. Passado e presente se misturam desde $o$ ato em que a imagem é clicada até o momento em que atinge o olhar de quem visita a exposição. As fotografias revelam o instante ínfimo de brecha que faz o sujeito facilmente associar a algum vestígio de cena na memória justamente por serem signos tão comuns, acabando por ativar novas histórias, reescrevendo fantasias antes esquecidas, mas que durante a exposição são tensionadas ao ponto de serem ou não rememoradas. Visualmente o branco não somente dificulta a construção por completo da imagem como está para além disso, já que se coloca como uma presença forte e constante de algo que nunca se revelará por completo. E isto aparece em toda a exposição.

A exposição Charif Benhelima: Polaroids, 1998-2012 esteve aberta à visitação pública no Museu Oscar Niemeyer, Curitiba, de 5 de dezembro de 2015 a 8 de maio de 2016.

Como citar: SANTOS, Vanessa. A estética do vazio nas polaroids de Charif Benhelima [resenha crítica da mostra Charif Benhelima: Polaroids, 1998-2012, Museu Oscar Niemeyer, Curitiba]. Poiésis, Niterói, v. 19, n. 32, p. 175-178, jul./ dez. 2018. doi: http://dx.doi.org/10.22409/poiesis.1932.175-178

Poiésis, Niterói, v. 19, n. 32, jul./dez. 2018. 